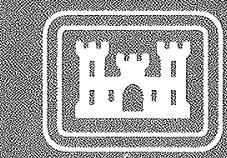

Us irmy Corps

of Enginears
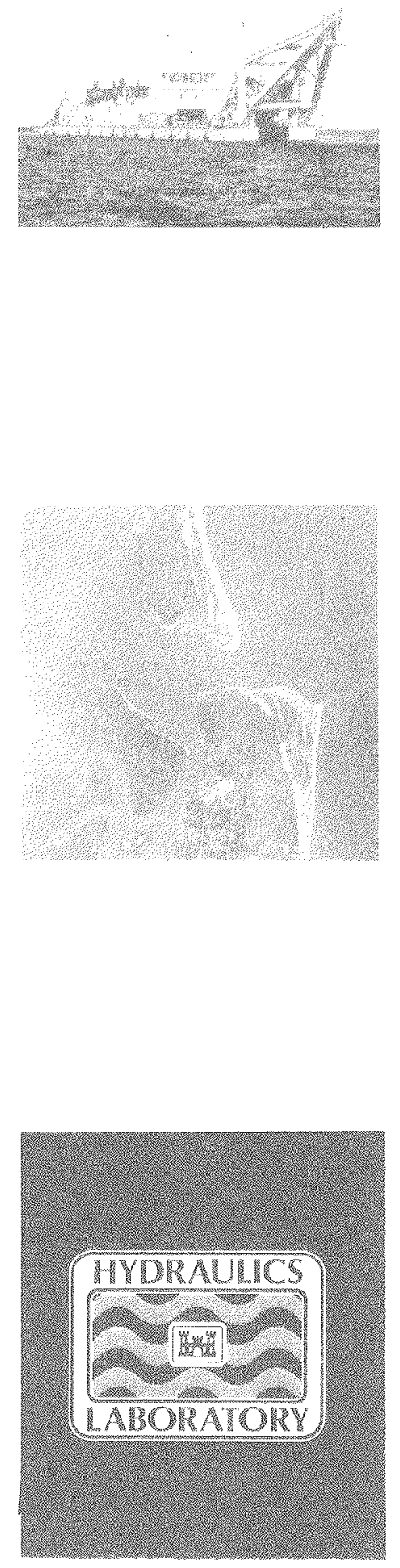

MISCELANYBRAULLSS LAB COPY

\section{FEASIBILITY OF SAND BYPASSING SYSTEMS FOR REDUCING MAINTENANCE DREDGING IN THE ST. MARYS RIVER ENTRANCE CHANNEL}

\author{
by
}

David R. Richards

Hydraulics Laboratory

and

James E. Clausner

Coastal Engineering Research Center

DEPARTMENT OF THE ARMY

Waterways Experiment Station, Corps of Engineers

PO Box 631, Vicksburg, Mississippl 39181-0631

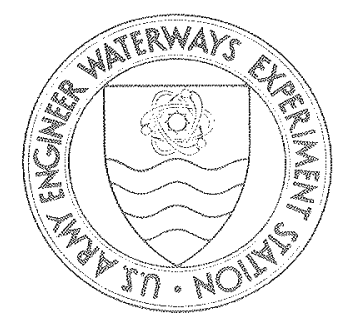

September 1988

Final Report

Approved For Public Release; Distribution Untimited

Prepared for DEPARTMENT OF THE NAVY Officer in Charge of Construction. Trident St. Marys, Georgia 31558

and

DEPARTMENT OF THE NAVY

Strategic Systems Program Office

Washington, DC 20376 
Destroy this report when no longer neded. Donot return is to the oringator:

The findmgs in this ropor are not he constued as an offich

Deparment of the Amy postion uness so desimated by other authorized documens.

The contents of this report are not to be used for advertsing, publication, of promotionat putposes. Givation of trade names does not constute an oficial endorement or approval of the use of such commercial products. 
Unclassified

SECURITY CLASSIFICATION OF THIS PAGE

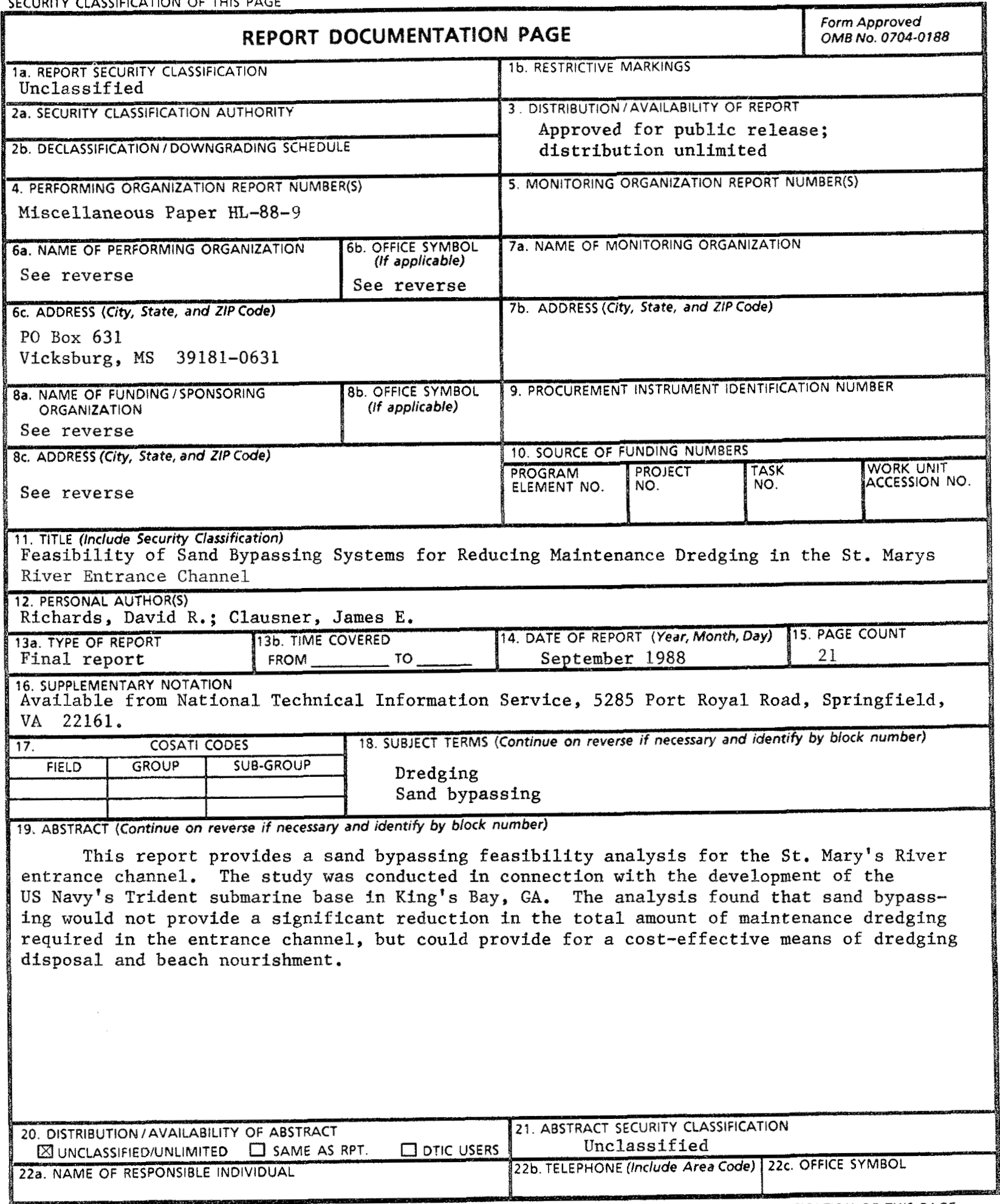


$6 a$ and $b$. NAME AND OFFICE SYMBOL OF PERFORMING ORGANIZATION (Continued). USAEWES, Hydraulics Laboratory, CEWESHE-E; and USAEWES, Coastal Engineering Research
Center, CEWESCD-S.

8a and c. NAME AND ADDRESS OF FUNDING/SPONSORING ORGANIZATION (Continued).

Department of the Navy, Officer in Charge of Construction, Trident, St, Mary's, GA 31558; and Department of the Navy, Strategic Systems Program Office, Washington, DC 20376. 


\section{Preface}

In September 1984, the US Army Engineer Waterways Experiment Station (WES) was requested by the US Navy, Officer in Charge of Construction, Trident, and the Strategic Systems Program office, to perform a feasibility study of the use of sand bypassing systems for reducing maintenance dredging requirements in the St. Marys River entrance channel that provides access to the Trident Submarine Base in Kings Bay, Georgia.

The study was conducted by Messrs. D. R. Richards of the Hydraulics Laboratory (HL) and J. E. Clausner of the Coastal Engineering Research Center (CERC), WES. Dr. R. E. Jensen of CERC performed longshore transport potential calculations that were used in the study. Supervision and assistance in the study were provided by Messrs. W. H. McAnally, Chief of the Estuaries Division; HL; E. C. McNair, Estuaries Division; and T. W. Richardson, Chief of the Coastal Structures and Evaluation Branch, CERC. This report was prepared by Messrs. Richards and Clausner.

COL Dwayne G. Lee, EN, is the Commander and Director of WES. Dr. Robert $W$. Whalin is the Technical Director. 


\section{Contents}

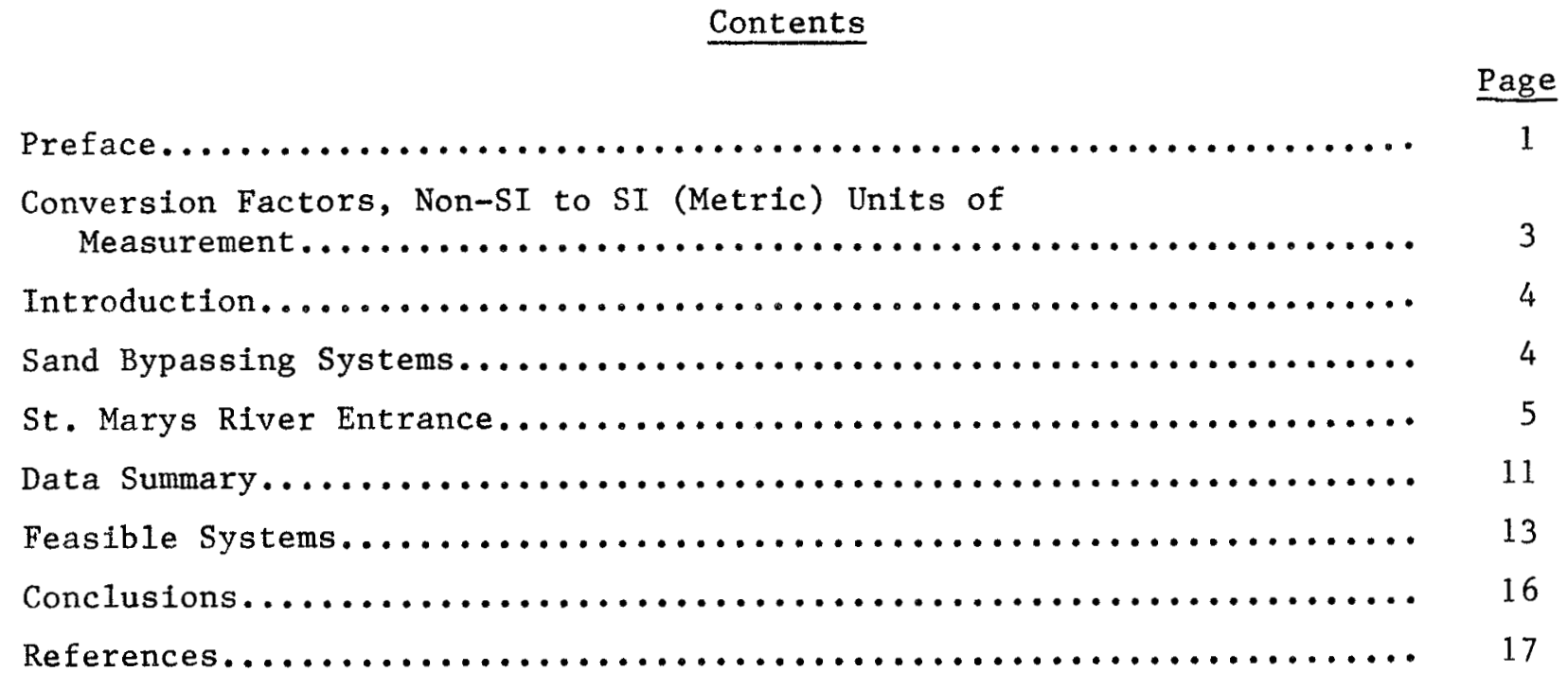




\section{Conversion Factors, Non-SI to SI (Metric)}

Units of Measurement

Non-SI units of measurement used in this report can be converted to SI (metric) units as follows:

Multiply

cubic yards

feet

inches

miles (US statute)

miles (US nautical)
By

0.7645549

0.3048

25.4

1.609344

1.852
To Obtain

cubic metres

metres

millimetres

kilometres

kilometres 
FEASIBILITY OF SAND BYPASSING SYSTEMS FOR

REDUCING MAINTENANCE DREDGING IN THE

ST. MARYS RIVER ENTRANCE CHANNEL

\section{Introduction}

1. The US Navy is currently involved in expanding its submarine base in Kings Bay, Georgia, to allow complete support facilities for the Navy's new fleet of Trident submarines. In doing so, major improvements to the navigation channels will be required to accommodate the larger and deeper draft ves-

sels. The improvements include extensive channel deepening, realignments, and possibly the construction of structures to assist in minimizing increased maintenance dredging requirements.

2. The US Army Engineer Waterways Experiment Station (WES) was requested by the Navy to provide guidance on predicting changes in the hydrodynamic and sedimentation characteristics throughout the Kings Bay area that would result from the channel improvements. The approach taken by WES Includes using physical and numerical models to make these projections both inside and outside the St. Marys River entrance.

3. In a separate request, the Navy asked WES to evaluate the use of sand bypassing systems as a means of minimizing shoaling and the required maintenance dredging in the St. Marys River entrance channe1. The purpose of this report is to give the findings on the feastbility of sand bypassing at the St. Marys River entrance.

\section{Sand Bypassing Systems}

4. Sand bypassing is a dredging technique that is used to promote the transfer of sand around barriers which interfere with the natural processes of longshore transport. It is typically used at coastal inlets where man-made jetties provide obstructions that result in entrance channel shoaling and erosion of downdrift beaches. Bypassing is most commonly accomplished by using dredge pumps and pipelines to provide the means of transportation for the sand. A wide variety of system configurations are possible and are generally designed to address site-specific requirements. 
5. Sand bypassing systems are normally classified by their degree of mobility (Richardson and McNair 1981). They can be classified as follows:

a. Fixed systems. These systems have their entire physical plant fixed in a single location. Common examples include dredge pumping systems that operate from a pump house or jet pump systems using fixed jet locations. These systems are effective only if the flow paths of the 1ittoral transport are predictable and the bypassing intakes can be located properly.

b. Mobile systems. The entire physical plant of mobile systems can be easily relocated throughout the project area depending on the location of the material to be bypassed. Typical examples include floating dredges or movable jet pump arrays. An advantage of mobile systems is that they can be moved to the areas of most concern which can vary considerably depending on the season or on particular storm events.

c. Semimobile systems. These systems as the name implies incorporate features from both fixed and mobile systems. They are mobile in the sense that they have limited mobility within a given area of the project site. They are fixed in the sense that they cannot be moved to all areas of the project site. An example would be dredge pump or jet pump systems that are attached to a portion of a jetty and can move along the jetty by the use of a railway.

6. The feasibility of bypassing at a particular inlet is controlled by the coastal processes in and around the inlet. Of major importance is the amount of sand to be bypassed (which is normally equal to the net longshore transport rate), the direction in which to bypass (downdrift or updrift), and the frequency at which bypassing needs to be conducted (continuous or intermittent).

\section{St. Marys River Entrance}

7. The St. Marys River forms the boundary between the States of Georgia and Florida (Figure 1). The river's entrance on the Atlantic Ocean is protected by rock jetties on the north and south sides. At high tide the jetties are completely awash and provide little protection in severe storms. of more importance to this study, however, is the fact that the jetties are permeable and allow significant quantities of sand to pass through and into the navigation channel. Once sand finds its way into the channel, tidal currents transport it into the offshore bar or into the flood tidal delta in the interior bay. The inlet itself is currently near a state of dynamic 


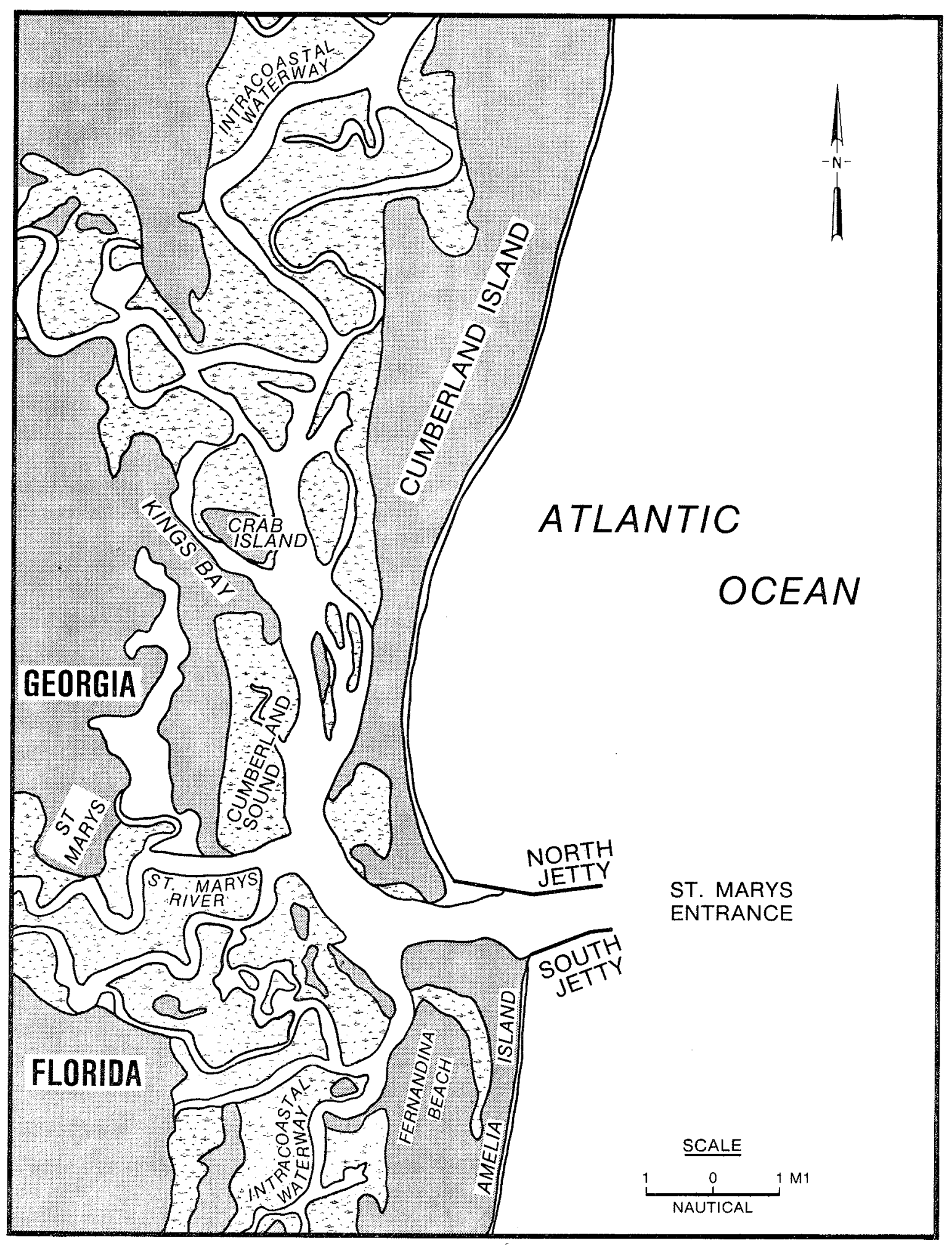

Figure 1. Vicinity map 
equilibrium and shows little evidence of changing its geometry despite the condition of the jetties. There do, however, appear to be significant quantities of sand deposited in the offshore bar and in the entrance channel leadings to Kings Bay. Extensive dredging will be required in the future to keep the bar channel passable to deep-draft vessels, so an effort to minimize the amount of dredging needed is desired. To achieve that end, sand bypassing is being considered.

8. An effective evaluation of sand bypassing at any location requires a thorough knowledge of the sediment transport regime. Estimates of sediment transport for St. Marys Entrance and the adjacent areas were collected from available sources and are summarized in Table 1.

Table 1

Yearly Sediment Transport Rate at St. Marys Entrance and Vicinity $(1,000 \mathrm{cu}$ yd)

\begin{tabular}{|c|c|c|c|c|c|}
\hline Source & South & North & $\mathrm{Net}$ & & Gross \\
\hline $\begin{array}{l}\text { COE* dredging records } \\
\text { St. Johns River }\end{array}$ & 600 & 100 & 500 & $S$ & 700 \\
\hline $\begin{array}{l}\text { University of } \\
\text { Florida }\end{array}$ & 380 & 142 & 238 & $S$ & 522 \\
\hline $\begin{array}{l}\text { F1orida Coastal } \\
\text { Engineers }\end{array}$ & $500+$ & 500 & $?$ & & $1000+$ \\
\hline $\begin{array}{l}\text { CERC, } * * \text { hindcast data, } \\
\text { Little Cumberland Is. }\end{array}$ & 700 & 335 & 365 & $S$ & 1035 \\
\hline $\begin{array}{l}\text { CERC, hindcast data, } \\
\text { St. Marys Entrance }\end{array}$ & 544 & 454 & & $S$ & 1008 \\
\hline $\begin{array}{l}\text { CERC, hindcast data, } \\
\text { Fernandina Beach }\end{array}$ & 503 & 547 & 44 & $\mathrm{~N}$ & 1050 \\
\hline $\begin{array}{l}\text { CERC, LEO data, } \\
\text { Atlantic Beach }\end{array}$ & 321 & 234 & & S & 551 \\
\hline
\end{tabular}

\footnotetext{
* US Army Corps of Engineers.

** Coastal Engineering Research Center.

$\dagger$ Littoral Environmental Observations.
} 
9. Estimates from the Corps of Engineers dredging records (USAED, Jacksonville, 1976) provide the only data that are actually based on physical measurement. These data, however, are for a site 21 miles south of the St. Marys Entrance. The same report contained estimates by the University of Florida but no documentation on how the figures were calculated.

10. The estimate from Florida Coastal Engineers contains the most information of any of our estimates. This firm produced a contract report to the Jacksonville District on beach erosion on Amelia Island. Based on volumetric calculations of the St. Marys Entrance and surrounding bathymetry over a 94-year period from 1881 to 1975, it was concluded that the construction of the jetties in 1881 to 1904 drastically changed the inlet hydraulics. Since the jetties are permeable to sand, they concluded that the inlet functions as a complete littoral trap. It was also stated that refraction effects from the large offshore bar east of the jetties cause waves to refract toward the inlet from virtually all directions. Fillets formed south of the south jetty and north of the north jetty seem to support this conclusion. Based on the volume changes seen in the area, formation of the offshore bar, and loss of sediment from the nearshore region and between the jetties, Florida Coastal Engineers estimated the average gross sediment transport to be approximately $1,000,000 \mathrm{cu} y d / y e a r$ over the last 100 years. In addition, they estimated that changes in the inlet have effected coastal processes for a distance of 16 miles, 8.5 to the north and 7.5 to the south.

11. During the course of this study, WES calculated longshore transport potential at three 10-nautical-mile-wide grid cells--Little Cumberland Island, St. Marys Entrance, and Fernandina Beach (Figure 2). The calculations were based on Phase III Wave Information Study (WIS) data (Jensen 1983) using the 1977 Shore Protection Manual (SPM) (CERC 1977) transport equations. The WIS wave data were calculated from meteorological data collected from 1956 to 1975. Pressure data at three-hour intervals were translated into pressure fields, which were used to generate surface winds. The wind was used as input to a numerical model to simulate wave generation, propagation, and decay. Transport potential was then calculated on a monthly basis from 1956 to 1975 . Deepwater wave information was refracted into the $10-\mathrm{m}$ contour, and then carried into shore with the calculated refraction angle assuming straight and parallel depth contours. The data calculated by the program are based on the average conditions within the 10-nautical-mile-wide grid cell. Consequently, 


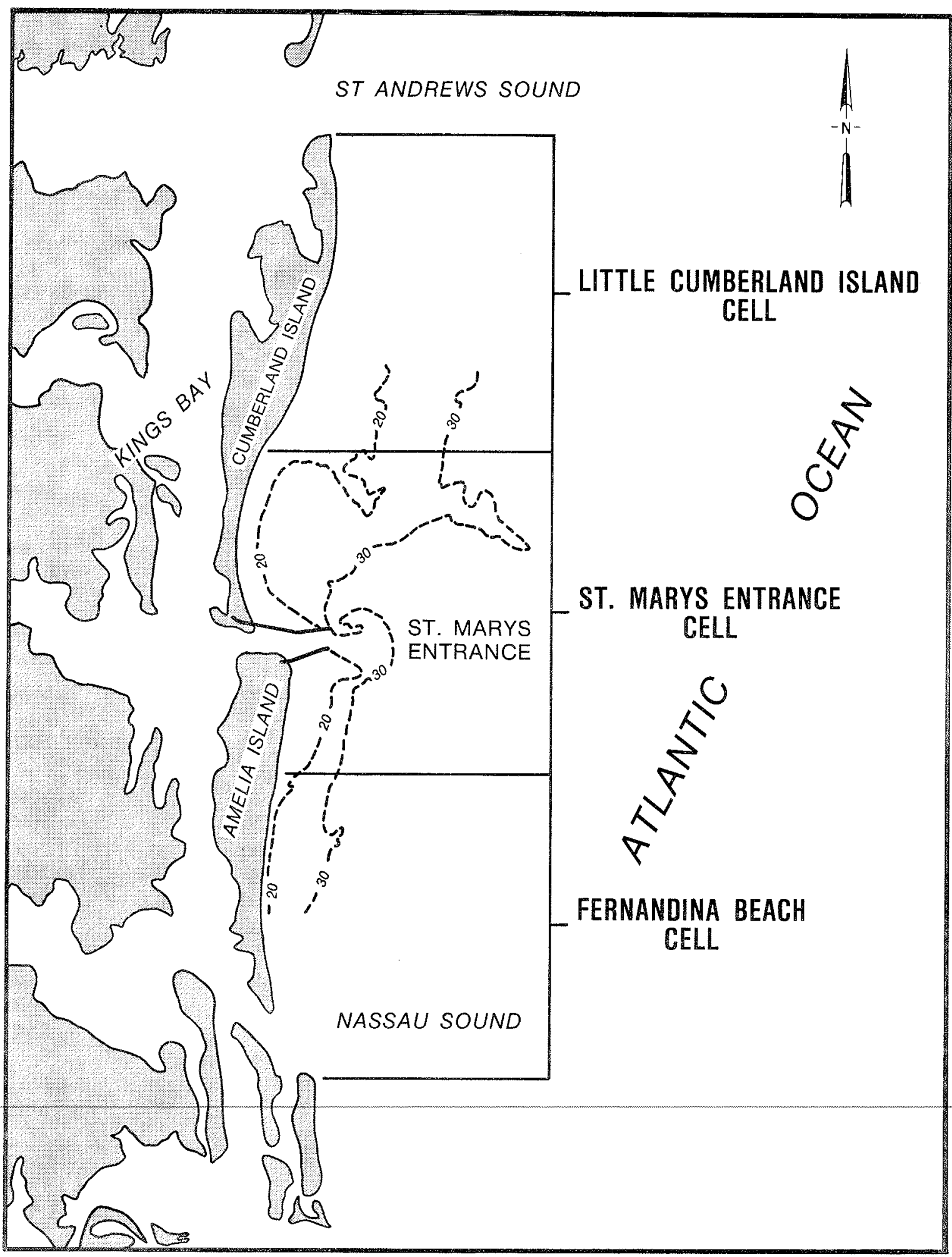

Figure 2. Map showing locations of WIS cells and offshore bathymetry 
the local effects of the jetties and offshore bar are not reflected in the data. The Little Cumberland Island cell (30.98N to $30.81 \mathrm{~N})$ is centered 10.8 nautical miles north of St. Marys entrance. The St. Marys Entrance cell $(30.81 \mathrm{~N}$ to $30.64 \mathrm{~N})$ is centered 0.7 nautical mile north of the inlet. The Fernandina Beach cel1 ( $30.64 \mathrm{~N}$ to $30.48 \mathrm{~N})$ is centered 9.3 miles south of the inlet. The numbers presented in Table 1 are the 20-year averages for the St. Marys entrance cell. As might be expected, yearly and monthly data vary widely from the average values.

12. Yearly net transport potential values for the St. Marys entrance cell are presented in Table 2. They ranged from $630,000 \mathrm{cu}$ yd to the south to

Table 2

Yearly Sediment Transport Values

for WIS St. Marys Cell

\begin{tabular}{|c|c|c|c|c|}
\hline & North & South & $\mathrm{Net}$ & Gross \\
\hline Year & $1,000 \mathrm{cu} \mathrm{yd}$ & $1,000 \mathrm{cu}$ yd & $1,000 \mathrm{cu} \mathrm{yd}$ & $1,000 \mathrm{cu} \mathrm{yd}$ \\
\hline 1956 & 260 & 520 & $260 \mathrm{~S}$ & 780 \\
\hline 1957 & 514 & 487 & $27 \mathrm{~N}$ & 1,000 \\
\hline 1958 & 502 & 596 & $96 \mathrm{~S}$ & 1,100 \\
\hline 1959 & 675 & 925 & $250 \mathrm{~S}$ & 1,600 \\
\hline 1960 & 542 & 558 & $16 \mathrm{~s}$ & 1,100 \\
\hline 1961 & 575 & 524 & $49 \mathrm{~N}$ & 1,100 \\
\hline 1962 & 510 & 450 & $60 \mathrm{~N}$ & 960 \\
\hline 1963 & 435 & 1,065 & $630 \mathrm{~s}$ & 1,500 \\
\hline 1964 & 750 & 651 & $99 \mathrm{~N}$ & 1,400 \\
\hline 1965 & 405 & 535 & $130 \mathrm{~s}$ & 940 \\
\hline 1966 & 520 & 680 & $160 \mathrm{~s}$ & $1 ; 200$ \\
\hline 1967 & 215 & 515 & $300 \mathrm{~s}$ & 730 \\
\hline 1968 & 247 & 224 & $23 \mathrm{~N}$ & 470 \\
\hline 1969 & 583 & 617 & $34 \mathrm{~s}$ & 1,200 \\
\hline 1970 & 457 & 363 & $94 \mathrm{~N}$ & 820 \\
\hline 1971 & 405 & 535 & $130 \mathrm{~s}$ & 940 \\
\hline 1972 & 440 & 760 & $320 \mathrm{~s}$ & 1,200 \\
\hline 1973 & 498 & 493 & $5 \mathrm{~N}$ & 990 \\
\hline 1974 & 329 & 361 & $32 \mathrm{~s}$ & 690 \\
\hline 1975 & 330 & 120 & $210 \mathrm{~N}$ & 450 \\
\hline
\end{tabular}

$210,000 \mathrm{cu}$ yd to the north. The average net transport potential was 15 percent of the gross transport. Gross values ranged from a low of 450,000 cu yd to a high of $1,600,000 \mathrm{cu}$ yd. Monthly averages, standard deviations, and maximum values of sediment transport potential for the St. Marys entrance cell are presented in Table 3. Data from the adjacent two cells have similar 
Table 3

Monthly Net Sediment Transport Values

for St. Marys Entrance

\begin{tabular}{|c|c|c|c|}
\hline Month & $\begin{array}{c}\text { Avg Net Sediment } \\
\text { Transport } \\
1,000 \text { cu yd } \\
\end{array}$ & $\begin{array}{c}\text { Standard } \\
\text { Deviation } \\
1,000 \text { cu yd } \\
\end{array}$ & $\begin{array}{c}\text { Max Net Sediment } \\
\text { Transport } \\
1,000 \text { cu yd } \\
\end{array}$ \\
\hline January & $25 \mathrm{~s}$ & 33 & $95 \mathrm{~S}$ \\
\hline February & $12 \mathrm{~N}$ & 51 & $140 \mathrm{~s}$ \\
\hline March & $25 \mathrm{~N}$ & 40 & $110 \mathrm{~N}$ \\
\hline April & $31 \mathrm{~N}$ & 32 & $110 \mathrm{~N}$ \\
\hline May & $9 \mathrm{~N}$ & 29 & $63 \mathrm{~N}$ \\
\hline June & $12 \mathrm{~N}$ & 31 & $100 \mathrm{~N}$ \\
\hline July & $10 \mathrm{~N}$ & 12 & $39 \mathrm{~N}$ \\
\hline August & $0.4 \mathrm{~s}$ & 13 & $29 \mathrm{~S}$ \\
\hline September & $43 \mathrm{~S}$ & 75 & $250 \mathrm{~S}$ \\
\hline October & $80 \mathrm{~S}$ & 84 & $240 \mathrm{~S}$ \\
\hline November & $32 \mathrm{~s}$ & 55 & $160 \mathrm{~S}$ \\
\hline December & $13 \mathrm{~s}$ & 61 & $160 \mathrm{~s}$ \\
\hline
\end{tabular}

ranges. In an average year, southerly transport occurs from September through January, while northerly transport takes place from February through July. The large standard deviations show the tremendous amount of variability in the monthly data. In fact, the standard deviations are larger than the average in every month. Data from the little Cumberland Island cell and the Fernandina Beach cell have similar amounts of variability in the monthly values.

13. The CERC transport potential estimate at Atlantic Beach, 26 miles south of St. Marys Entrance, is based on Littoral Environmental Observations (LEO) from 1978 to 1981 (Walton 1980; Schneider 1981). Sediment transport calculations were made using equations from the 1984 SPM. Unfortunately, the quality of observations was not good, nor were the records complete; however, the data are within the range of the other estimates. Monthly variations in the sediment transport values were similar to the hindcast data, with a majority of the southerly transport occurring in the fall and early winter and the northerly transport occurring in the spring and summer.

\section{Data Summary}

14. Reviewing the above results, longshore sediment transport in the 
vicinity of St. Marys Entrance may be best estimated at present by WIS hindcast results. The 20-year average gross transport rates from those calculations can account for the tremendous amount of sand moved offshore as documented by Florida Coastal Engineers. Bathymetric changes showed that approximately $100,000,000 \mathrm{cu}$ yd have moved from the nearshore zone in and around St. Marys Entrance to the offshore bar in the past 100 years, an average of

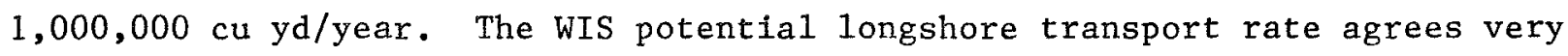
we11 with the actual changes that occurred. Also, based on bathymetric changes, Florida Coastal Engineers predicted southerly transport to be slightly higher than northerly transport. The WIS data support this conclusion, with an average net transport value of $90,000 \mathrm{cu}$ yd/year to the south.

15. Although the variations in monchly transport make precise transport values difficult to define, it appears that offshore bathymetry may produce a nodal point for sediment transport at St. Marys Entrance. The large gross transport ( 1 million cu yd) with little net drift $(90,000 \mathrm{cu}$ yd to the south) continues to provide a large amount of sand to the inlet. Porous jetties and tidal flow through the entrance combine to form an efficient means of moving the sand into the inlet and out onto the offshore bar. Local wave transformation effects from the jetties and offshore bar may increase the efficiency of this process by producing transport toward St. Marys Entrance from most any wave direction. The Jacksonville District estimates that the wave transformation effects extend up to 4 miles south of the jetties, with the majority of the effects occurring in the first mile. No estimate was made by the Jacksonville District of effects to the north, but it is reasonable to assume that the distance is similar.

16. Considering all of the longshore sediment transport estimates, it seems reasonable to proceed with the following assumptions for sand bypassing requirements for the St. Marys Entrance:

a. The average net yearly transport rate over the 10-nautical-mile reach that includes $\mathrm{St}$. Marys Entrance is approximately $90,000 \mathrm{cu}$ yd per year to the south.

b. The average yearly gross transport rate or the amount of material that is available for deposition in the entrance channel is approximately $1,000,000 \mathrm{cu}$ yd per year.

c. The average yearly maintenance dredging volume in the entrance and offshore channel is $475,000 \mathrm{cu}$ yd/year at present and predicted (Vemulakonda et a1. 1988) to be $780,000 \mathrm{cu}$ yd/year for the Trident Channel. 
Feasible Systems

17. Norma11y, sand bypassing systems are used to reduce the amount of maintenance dredging required in inlets that have a significant net longshore transport. The systems are ordinarily designed to bypass the net longshore transport to the downdrift beach. In doing so, the required maintenance dredging of the entrance channel will be diminished by this net amount. To the extent that the net transport comprises a large portion of the gross transport, bypassing can be extremely feasible and can provide significant cost savings. With regard to the St. Marys entrance, the net transport of $90,000 \mathrm{cu} y d / y e a r$ to the south is a small portion of the gross transport of $1,000,000 \mathrm{cu}$ yd/year. Sand bypassing, in the unlikely event that it would be totally effective, would remove less than 10 percent of the gross transport. It does not appear that bypassing the net 1ittoral transport of $90,000 \mathrm{cu}$ yd/ year will significantly reduce maintenance dredging requirements in the entrance channe1. Therefore, sand bypassing for the specific purpose of reducing maintenance dredging volumes in the entrance channel does not appear to be feasible.

18. Sand bypassing may be considered feasible based on other considerations and more limited expectaticns. There is a possibility that beaches in the city of Fernandina Beach would be improved by bypassing sand from the shoal just south of the north jetty (Figure 3). According to the Jacksonville District, this shoal is gradually accreting over time and the removal of sand in a bypassing operation would not adversely affect the structural integrity of the north jetty. The bypassed material could easily be transferred without disrupting navigation by pumping it through a pipeline placed under the channel. The discharge point should be at least 2 miles south of the south jetty to minimize the amount of sand moved to the north by local wave effects. The most effective time to conduct the bypassing from a coastal processes standpoint would be during August. The fall and winter waves will then move the bypassed sand to the south providing nourishment to the eroded beaches on Amelia Is land.

19. Sand bypassing from the interior shoal to the beaches of Amelia Island may offer benefits to the Navy and to the beaches of Amelia Island. Since maintenance dredging will be required periodically in the entrance channel and the interior shoal, this material will have to be disposed of in 


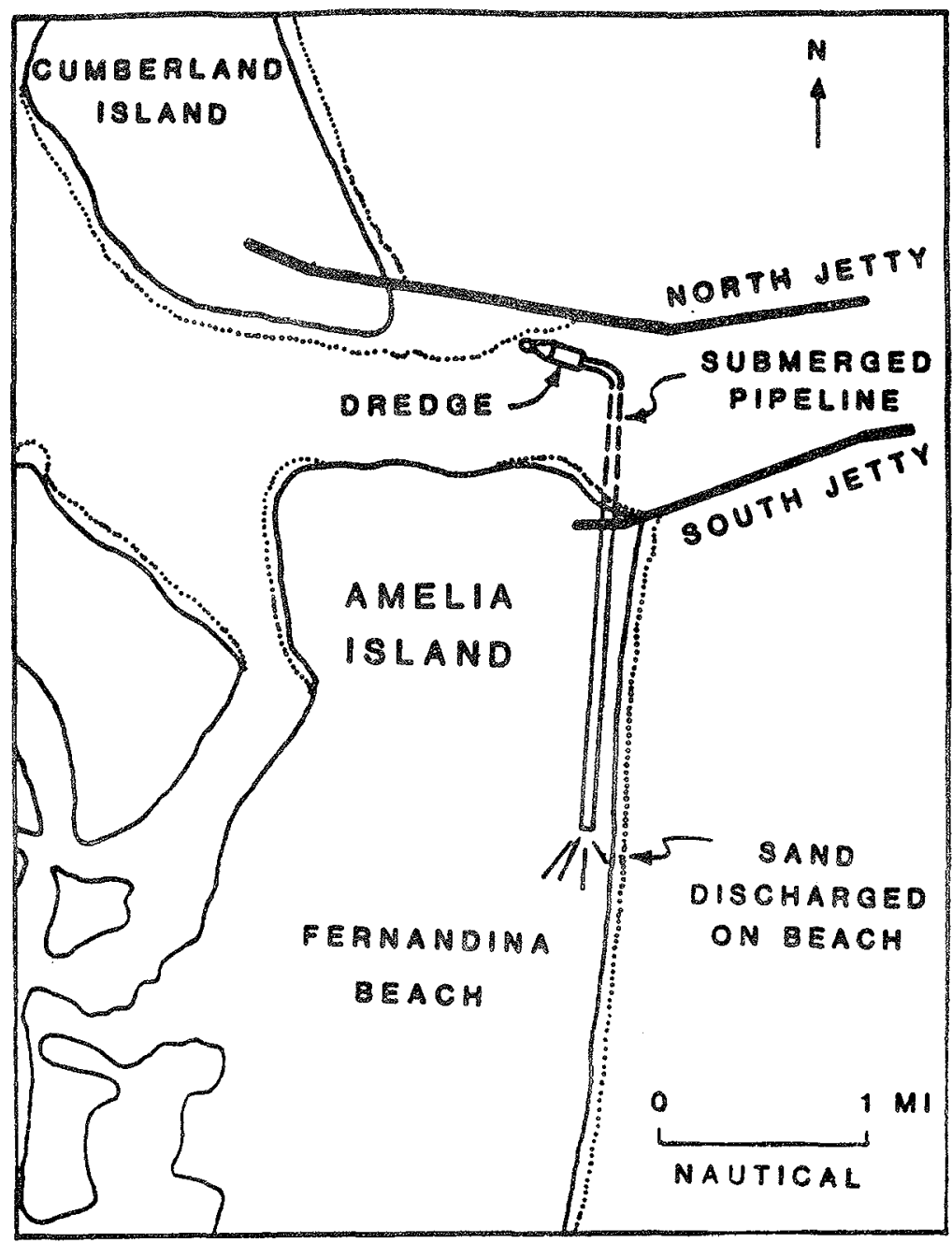

Figure 3. Schematic of dredge bypassing sand from the interior shoal

either a confined disposal area of which there is limited capacity in Kings Bay or in open water which requires expensive transportation costs. Based on disposal problems alone, this manner of bypassing may be feasible. Another benefit of bypassing in this way involves the economics of dredging. Large quantities of material can be moved in a short period more easily in protected waters. It may be more economical to contract a large cutterhead dredge (larger than $18 \mathrm{in.)}$ to dredge the material in protected waters before it is transported offshore where more expensive hopper dredges may be required. The cutcerhead dredge could come in once a year during the month of August and pump at a high production rate for a relatively short period of time. Dredging the interior shoal would be easy digging and the jetties would provide the required wave protection for the dredge. By dredging just the top 3.7 ft from 
the 1,450 - by 5,100-ft shoa1, as much as 500,000 cu yd could be removed and transported to Fernandina Beach. This would provide a substantial amount of nourishment initially and smaller amounts could be bypassed thereafter depending on the needs of the beaches and disposal requirements from maintaining the entrance channel.

20. Another option in the above scenario is using cutterhead dredges that may already be performing maintenance work in the upper Kings Bay to do the bypassing by temporarily suspending operations during the month of August and then returning to complete Kings Bay after the bypassing has been completed. In this way, mobilization and demobilization costs could be minimized compared to setting up a separate contract to do bypassing with perhaps a different contractor.

21. Cutterheads are not the only type of mobile system that could be feasible. Hopper dredges have been used to maintain the entrance channel and could be used in a bypassing scenario. In fact, the Corps of Engineers hopper dredge, Comber, was used in 1982 to provide nourishment to Fernandina Beach. After filling its hoppers, the dredge tied up to mooring barges and pumped the sand through a submerged pipeline to Fernandina Beach. Bypassing could be accomplished using hopper dredges in this type of application; however, an economic comparison could show cutterhead dredges to be more economical. A choice between these two types of dredges should be based on economics and availability rather than the intrinsic properties of the dredge types.

22. Other types of bypassing systems were considered but none showed the promise of the entirely mobile systems. Fixed systems would not be feasible due to the large area of deposition behind the north jetty and the difficulty in locating bypassing intakes. Further, they would require large capital costs to be effective, especially when so little of the channel shoaling would be remedied. Semimobile systems were also considered but the limited paved access roads and the sensitive nature of the park lands on Cumberland Island make these systems logistically difficult to support. The mobile systems proposed require no land access on Cumberland Island and do not require the high capital costs of construction and extended labor costs for maintaining a fixed or semimoblle system. 


\section{Conclusions}

23. The development of a comprehensive sand bypassing system for the St. Marys River entrance is not likely to provide significant reductions in the amounts of maintenance dredging required in the St. Marys River entrance channe1. This conclusion is based on several sources of data that show the net transport rate of $90,000 \mathrm{cu}$ yd/year to be a small portion of the gross transport rate of $1,000,000 \mathrm{cu}$ yd/year. Sand bypassing is most effective when the net rate comprises a large portion of the gross rate. Bypassing effectively removes the net transport amounts from the channel maintenance dredging requirements.

24. Bypassing may be considered feastble based on other considerations and more limited expectations. Maintenance dredging will continue to be needed in the entrance channel as will disposal sites for this material. The material consists of clean sands that can be used for nourishing beaches. More detailed studies could indicate whether bypassing the material in the manner described herein would be more economical than allowing the material to enter the channel where it would likely be removed by conventional dredging equipment. 
Jensen, R. E. 1983 (Jan). "Atlantic Coast Hindcast, Shallow-Water Significant Wave Information," WIS Report 9, US Army Engineer Waterways Experiment Station, Vicksburg, MS.

Richardson, T. W., and McNair, E. C., Jr. 1981 (Sep). "A Guide to the Planning and Hydraulic Design of Jet Pump Remedial Sand Bypassing Systems," Instruction Report HL-79-1, US Army Engineer Waterways Experiment Station, Vicksburg, MS.

Schneider, C. 1981. "The Littoral Environmental Observation (LEO) Program," CETA 81-5, Coastal Engineering Research Center, Fort Belvoir, VA.

US Army Engineer District, Jacksonville. 1976. "Beach Erosion Control Study Nassau County," Contract No. DACW17-75C-0039, submitted by Florida Coasta1 Engineers, Jacksonville, FL.

US Army Coasta1 Engineering Research Center. 1977. "Shore Protection Manual," Fort Belvoir, VA.

Vemulakonda, S. R., Scheffner, N. W., Earickson, J. A., and Chou, L. W. 1988 (Apr). "Kings Bay Coastal Processes Numerical Mode1," Technical Report CERC-88-3, US Army Engineer Waterways Experiment Station, Vicksburg, MS.

Walton, T. L., Jr. 1980. "Computation of Longshore Energy Flux Using LEO Current Observations," CETA 80-3, Coastal Engineering Research Center, Fort Belvoir, VA, for US Army Engineer Waterways Experiment Station, Vicksburg, MS. 